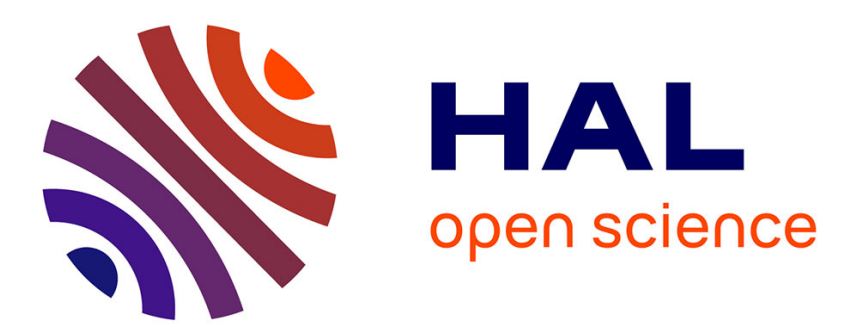

\title{
Xenogeneic bone filling materials modulate mesenchymal stem cell recruitment: role of the Complement C5a
}

Charlotte Jeanneau, Chloé Le Fournis, Imad About

\section{To cite this version:}

Charlotte Jeanneau, Chloé Le Fournis, Imad About. Xenogeneic bone filling materials modulate mesenchymal stem cell recruitment: role of the Complement C5a. Clinical Oral Investigations, In press, 10.1007/s00784-019-03087-5 . hal-02462632

\section{HAL Id: hal-02462632 \\ https://hal.science/hal-02462632}

Submitted on 15 Apr 2020

HAL is a multi-disciplinary open access archive for the deposit and dissemination of scientific research documents, whether they are published or not. The documents may come from teaching and research institutions in France or abroad, or from public or private research centers.
L'archive ouverte pluridisciplinaire HAL, est destinée au dépôt et à la diffusion de documents scientifiques de niveau recherche, publiés ou non, émanant des établissements d'enseignement et de recherche français ou étrangers, des laboratoires publics ou privés. 


\title{
Xenogeneic bone filling materials modulate mesenchymal stem cell recruitment: role of the Complement $\mathrm{C} 5 \mathrm{a}$
}

\author{
Charlotte Jeanneau ${ }^{1} \cdot$ Chloé Le Fournis $^{1} \cdot \operatorname{Imad}^{\text {About }}{ }^{1}$
}

$\mathrm{R}$

\begin{abstract}
Objectives When bone filling materials are applied onto the periodontal tissues in vivo, they interact with the injured periodontal ligament (PDL) tissue and modulate its activity. This may lead to mesenchymal stem cells (MSCs) recruitment from bone marrow and initiate bone regeneration. Our hypothesis is that the filling materials affect PDL cells and MSCs functional activities by modulating PDL C5a secretion and subsequent MSCs proliferation and recruitment.

Materials and methods Materials' extracts were prepared from 3 bone-grafting materials: Gen-Os ${ }^{\circledR}$ of equine and porcine origins and bovine Bio-Oss ${ }^{\circledR}$. Expression and secretion of C5a protein by injured PDL cells were investigated by RT-PCR and ELISA. MSCs proliferation was analyzed by MTT assay. C5a binding to MSCs C5aR and its phosphorylation was studied by ELISA. C5a implication in MSCs recruitment toward injured PDL cells was investigated using Boyden chambers. Results MSCs proliferation significantly increased with Gen-Os ${ }^{\circledR}$ materials but significantly decreased with Bio$\mathrm{Oss}^{\circledR}$. C5a secretion slightly increased with Bio-Oss ${ }^{\circledR}$ while its level doubled with Gen-Os ${ }^{\circledR}$ materials. C5a fixation on MSCs C5aR and its phosphorylation significantly increased with Gen-Os ${ }^{\circledR}$ materials but not with Bio-Oss ${ }^{\circledR}$. MSCs recruitment toward injured PDL cells increased with the three materials but was significantly higher with Gen-Os ${ }^{\circledR}$ materials than with Bio-Oss ${ }^{\circledR}$. Adding $\mathrm{C} 5 \mathrm{a}$ antagonist inhibited MSCs recruitment demonstrating a C5a-mediated migration. Conclusions Injured PDL cells secrete C5a leading MSCs proliferation and recruitment to the PDL injured cells. Gen-Os ${ }^{\circledR}$ materials enhanced both C5a secretion by injured PDL cells and MSCs recruitment. Bio-Oss ${ }^{\circledR}$ inhibited MSCs and was less efficient than Gen-Os ${ }^{\circledR}$ materials in inducing MSCs recruitment.

Clinical relevance Within the limits of this study in vitro, Gen-Os ${ }^{\circledR}$ filling materials have a higher potential than Bio-Oss ${ }^{\circledR}$ on MSCs proliferation and C5a-dependent recruitment to the PDL injury site and the subsequent bone regeneration.
\end{abstract}

Keywords Xenogenic bone filling material $\cdot$ Bone regeneration $\cdot$ Complement C5a $\cdot$ Stem cell recruitment

\section{Introduction}

Alveolar bone crest preservation after tooth extraction is a real challenge in implantology as dimensional ridge alteration following tooth extraction, including hard and soft tissues loss, reduces the optimal implant placement [1]. Xenogenic filling materials are used to support bone regeneration on the fresh extraction pocket and to allow a better implant fixation $[2,3]$.

Clinical and histological investigations have demonstrated new bone formation after the application of materials $[4,5]$.

Imad About

imad.about@univ-amu.fr

1 Aix Marseille Univ, CNRS, ISM, Inst Movement Sci, Marseille, France
Indeed, when porcine bone was applied as xenograft filling material for post-extraction ridge preservation, $\mu \mathrm{CT}$ and histological examination revealed that the defect was homogeneously filled with trabecula. Over time, the filling material was replaced by newly formed bone [6]. A clinical trial comparing bone dimensional changes following tooth extraction to extraction plus ridge preservation using cortico-cancellous porcine bone showed a decreased resorption of hard tissue ridge and formation of new bone between the porcine bone particles indicating that the material acts as a natural scaffold for new bone formation $[4,7]$.

At the cellular and molecular levels, bone regeneration requires mesenchymal stem cells (MSCs) recruitment at the injured site. MSCs are under the control of bone microenvironment specific mediators [8]. Upon bone injury, MSCs are mobilized into the peripheral blood by monocyte chemoattractant protein (MCP)-1, produced predominantly 
by macrophages [9]. Activated MSCs CD44 receptors recognize hyaluronic acid (HA) on endothelial cells and enhance their migration [10]. Pro-inflammatory cytokines, such as interferon- $\gamma$ and TNF- $\alpha$, increase the production of matrix metalloproteinases (MMPs) by MSCs, thereby enhancing their capacity to migrate through the extracellular matrix [11].

Recent investigations have reported that bone-filling materials allow MSCs migration into the bone defect and induce their differentiation $[12,13]$. These bone-filling materials can act as 3-dimensional scaffold allowing adsorption of growth factors secreted from neighboring tissues and their delivery [14].

In bone fracture and remodeling, the recruitment of MSCs has been reported to be influenced by the complement $\mathrm{C} 3 \mathrm{a}$ and C5a fragments [15].

Complement is a powerful plasmatic protein cascade of innate immunity. It is composed of more than 40 plasma and membrane proteins and can be activated by three pathways: the classical, alternative, or lectin pathway. Complement activation can be induced by infectious agents, traumatic injuries, or after contact between complement proteins and biomaterials [16]. This activation leads to the production of potent active mediators including the biologically active C5a fragment. C5a is a protein released from Complement component $\mathrm{C} 5$ cleavage by protease $\mathrm{C} 5$-convertase into $\mathrm{C} 5 \mathrm{a}$ and $\mathrm{C} 5 \mathrm{~b}$ fragments. During the inflammatory process, C5a is known as an anaphylatoxin mainly involved in the vasodilatation of blood vessels and the subsequent recruitment of $\mathrm{C} 5 \mathrm{a}$ receptor (C5aR)-expressing cells to the inflammatory site. C5a interacts with its receptor C5aR on the surface of cells such as macrophages or neutrophils. C5aR is a member of the Gprotein-coupled receptor superfamily, the ligand binding leads to phosphorylation of six serine residues [17]. In addition to its expression by the immune cells, C5aR expression has been demonstrated in several non-immune cell types such as endothelial cells, astrocytes, skin, heart, and human MSCs [18]. Recent data have demonstrated its implication in pulp MSCs recruitment towards injured or LTA-stimulated fibroblasts [19, 20].

While the complement proteins are mainly produced by the liver, recent works have shown a local expression and synthesis of complement molecules by cells exposed to trauma, infectious agents [21], or with a terminal circulation such as dental pulp fibroblasts [20]. Indeed, after lipoteichoic acid (LTA) stimulation, pulp fibroblasts secrete C5a complement protein which allows a selective recruitment of dental pulp stem cells expressing C5aR [19].

The periodontal ligament (PDL) cells can be exposed to trauma and infectious agents and their capacity to secrete complement proteins has never been investigated.

Use of bone-filling materials for alveolar bone crest preservation after tooth extraction implies interaction of the material with injured PDL cells. Understanding MSCs recruitment toward injured PDL/bone-filling site and the modulation of this process by bone-filling materials allows elucidating the cellular and molecular mechanisms involved in MSCs recruitment and making a better choice of the appropriate filling material. However, to the best of our knowledge, no studies have been performed so far to check PDL cells capacity to express and secrete complement proteins nor the role of complement activation in MSCs recruitment to the injury/filling material's application site.

Our hypothesis was that PDL cells express C5 and that they are able to produce the active C5a fragment which can be involved in MSCs proliferation and recruitment. We further hypothesized that these events may be modulated by bonegrafting materials.

PDL cells were injured to mimic the PDL injury after tooth extraction. Injured PDL cells were incubated with bone-filling materials' extracts to simulate the interaction between the injured PDL cells and the materials. C5 complement gene expression and C5a protein secretion by PDL cells was analyzed. The effects of materials on MSCs proliferation was studied by the MTT Assay. C5a fixation on MSCs, the C5aR phosphorylation, and the subsequent MSCs recruitment was analyzed using ELISA and Boyden chambers.

\section{Material and methods}

\section{Reagents}

All cell culture media and reagents were purchased from Dominique Dutscher (Brumath, France). Gen-Os ${ }^{\circledR}$ materials (named Gen-Os ${ }^{\circledR}$ FE: equine origin and Gen-Os ${ }^{\circledR}$ FS: swine origin) were obtained from Tecnoss Dental (Turin, Italy) and Bio-Oss ${ }^{\circledR}$ material from Geistlich (Wolhusen, Switzerland).

\section{Human periodontal ligament cell culture}

PDL cells were obtained from immature third molars freshly extracted for orthodontics reasons in compliance with French legislation (informed patients consent and institutional review board approval of the protocol used) by the explant outgrowth method [22]. Cells were cultured in Minimum Essential Medium (MEM) supplemented (10\% fetal bovine serum (FBS), $2 \mathrm{mM}$ glutamine, $100 \mathrm{UI} / \mathrm{mL}$ penicillin, $100 \mu \mathrm{g} / \mathrm{mL}$ streptomycin, and $0.25 \mu \mathrm{g} / \mathrm{mL}$ amphotericin B) at $37{ }^{\circ} \mathrm{C}$, $5 \% \mathrm{CO}_{2}$ atmosphere.

\section{Human bone marrow mesenchymal stem cell culture}

Human MSCs from human bone marrow were purchased from PromoCell (Heidelberg, Germany) and were cultured in MSCs Growth Medium 2 (MGM-2) (PromoCell) at 37 ${ }^{\circ} \mathrm{C}, 5 \% \mathrm{CO}_{2}$ atmosphere. 


\section{Bone-filling material extracts}

To obtain bone-filling materials' extracts, samples of Gen-Os ${ }^{\circledR}$ $\mathrm{FE}$ (equine origin) and FS (porcine origin) and bovine Bio-Oss ${ }^{\circledR}$ were incubated in serum-free MGM-2 at $20 \mathrm{mg} / \mathrm{mL}\left(37^{\circ} \mathrm{C}, 24\right.$ h). Samples were centrifuged and the supernatants were collected. The supernatants containing the materials' extracts were used for the next experimental protocols as demonstrated (Fig. 1). Use of $20 \mathrm{mg} / \mathrm{mL}$ was based on preliminary works where increasing quantities of bone-filling materials/medium volume were tested for their toxicity to PDL cells using the MTT assay. The rationale was to use the highest ratio without any toxic effects to PDL cells. This ratio used in a previously published work demonstrated angiogenic and osteogenic potentials [23].

\section{Conditioned media preparation}

PDL cells were cultured at confluence in 12-well plates. Cells were injured with sterile scalpels in vertical and horizontal directions (5 in each direction) in serum-free MEM media and incubated with the materials' extracts or serum-free MGM-2 control media for $24 \mathrm{~h}$ and $72 \mathrm{~h}$. The supernatants were then harvested and will be called conditioned media.

\section{RT-PCR}

Total RNAs were isolated using a PureLink RNA mini kit (Life Technologies) from injured PDL cells after incubated with the materials' extracts. RNA samples $(2 \mathrm{mg})$ were reverse-transcribed by using a reverse transcription AMV system (Promega, Madison, WI). Primers used were (C5a) forward, 5'-AGTGTGTGGAAGGGTGGAAG-3', and reverse, 5' - G T T C T C T C G G G C T T C A A C A G - 3'; and (Glyceraldehyde 3-phosphate dehydrogenase [GAPDH] as an internal control) forward, 5'-GAAGGTGAAGTT CGGAGTC-3', and reverse, 5'- GAAG ATGGTGAT GGGATTTC- $3^{\prime}$. PCR conditions were $95{ }^{\circ} \mathrm{C} 5 \mathrm{~min}\left(95{ }^{\circ} \mathrm{C}\right.$ $\left.30 \mathrm{sec}, 55^{\circ} \mathrm{C} 30 \mathrm{sec}, 72{ }^{\circ} \mathrm{C} 45 \mathrm{sec}\right) \times 30$, and $72{ }^{\circ} \mathrm{C} 12 \mathrm{~min}$. PCR products were separated on $1 \%$ agarose gels.

\section{C5a quantification}

C5a concentrations were determined in conditioned media by the enzyme-linked immunosorbent assay (ELISA) according to the manufacturer's instructions (DuoSet ELISA Development System kit, R\&D Systems, Lille, France).

\section{C5a/C5aR binding and C5aR phosphorylation}

MSCs were seeded overnight at $\left(3000 \mathrm{cells} / \mathrm{cm}^{2}\right)$ in 96-well microplates. Cells were incubated with conditioned media for 5 $\mathrm{min}$. In parallel, cells were also pre-incubated for $5 \mathrm{~min}$ with or without $10 \mathrm{nM}$ of W54011, a specific C5aR antagonist (Merck, Darmstadt, Germany). After washing, cells were fixed (3\% paraformaldehyde, $20 \mathrm{~min}$ ) and saturated (5\% BSA, $1 \mathrm{~h}$ ). C5a/C5aR binding was visualized by biotinylated mouse anti-human $\mathrm{C} 5 \mathrm{a}$



Fig. 1 A schematic view of the experimental setup. Materials' extracts were obtained by incubation of bone-filling materials in MGM-2 (24 h, $37^{\circ} \mathrm{C}, 5 \% \mathrm{CO}_{2}$ ). Physically injured PDL cells were then incubated with these extracts for $24 \mathrm{~h}$ or $72 \mathrm{~h}$. C5 gene expression was analyzed directly on cells by RT-PCR while C5a secretion was quantified by ELISA.

Supernatants from injured PDL cells incubated with materials' extracts (conditioned media) were applied on MSCs cultures to evaluate C5a binding to MSCs C5aR and its phosphorylation by ELISA, to quantify their proliferation using MTT assay and their migration using Boyden chambers 
$\operatorname{IgG}(2 \mu \mathrm{g} / \mathrm{mL}, 2 \mathrm{~h})$ followed by Streptavidin-HRP (20 min) and substrate solution (20 min) (R\&D Systems, Lille, France). C5aR phosphorylation was visualized by biotinylated rabbit antihuman C5aR-p(Ser338) (Abcam, Paris France) $(2 \mu \mathrm{g} / \mathrm{mL}, 2 \mathrm{~h}$ ) followed by Streptavidin-HRP (20 $\mathrm{min})$ and substrate solution (20 min) (R\&D Systems, Lille, France). Optical densities were measured at $650 \mathrm{~nm}$ using an automatic microplate spectrophotometer (Metertech Inc., Taipei, Taiwan). C5a/C5aR binding and $\mathrm{C} 5 \mathrm{aR}$ phosphorylation are expressed as percentage of the control condition.

\section{Mesenchymal stem cell proliferation}

MSCs were cultured at low density $\left(1000\right.$ cells $\left./ \mathrm{cm}^{2}\right)$ in $96-$-well culture plates for $24 \mathrm{~h}$. Media were replaced by conditioned media. After 3, 6, and 9 days, the supernatants were removed and a succinyl dehydrogenase (MTT) assay was performed as described [24] to measure cell proliferation [25]. Results are expressed as percentage of control (conditioned media without material extract).

\section{Mesenchymal stem cell migration}

Migration was studied using Boyden chambers $(8 \mu \mathrm{m}$ pore size) in 12-well plates. Confluent PDL cells were cultured in the lower chamber. Cells were then injured with scalpels and incubated with either materials' extracts or serum-free MGM2 control media. MSCs $\left(10^{4}\right.$ cells $\left./ 100 \mu \mathrm{l}\right)$ were seeded in the upper chamber with or without the C5aR antagonist, W54011 $(10 \mathrm{nmol} / \mathrm{L})$. After $24 \mathrm{~h}$, cells migrating to the lower side of the membrane were fixed (15 min, cold ethanol 70\%) and stained with hematoxylin (20 min). The number of migrating cells was counted in 5 random fields using light microscopy. Results are expressed as percentage of control (cells migrating in response to injured PDL incubated in serum-free MGM-2).

\section{Statistical analysis}

All the experiments were performed in triplicates with 3 different cell populations. Statistical significance was determined using the Student's $t$ test to compare two sets of data from the different treatments and their respective controls. Data were expressed as means \pm SD and considered significant for $p<0.05$.

\section{Results}

\section{Gen-0s ${ }^{\circledR}$ bone-filling materials increase $\mathrm{C} 5$ a secretion by injured periodontal ligament cells}

Reverse transcriptase (RT)-PCR analysis shows that injured PDL cells express $\mathrm{C} 5$ gene regardless of the bone-filling material extract used (Fig. 2a).

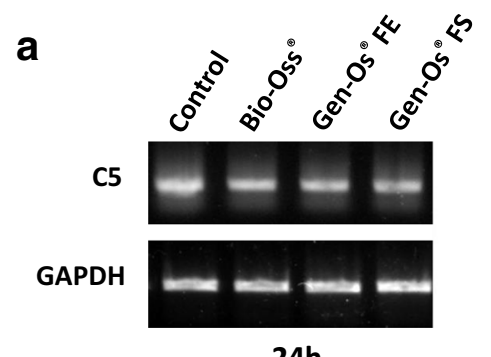

$24 \mathrm{~h}$
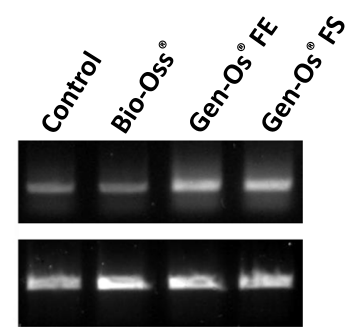

$72 \mathrm{~h}$

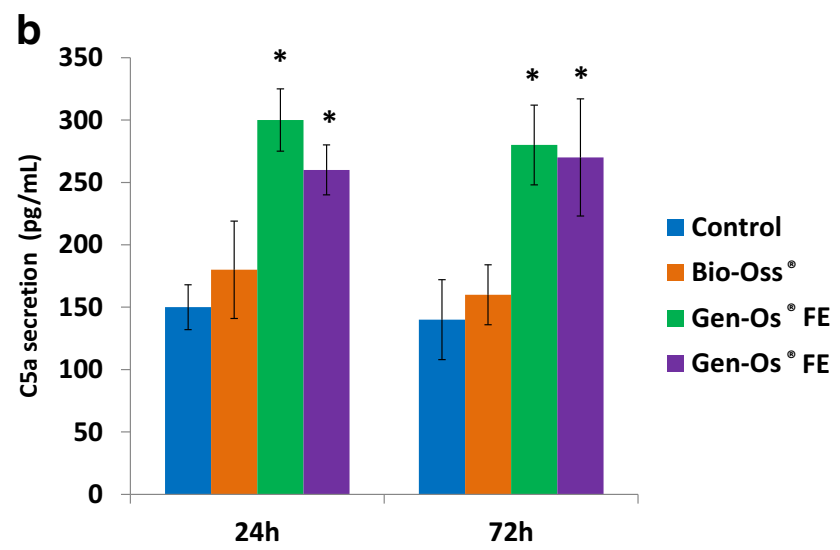

Fig. 2 C5 gene expression and C5a secretion by PDL cells. a C5 gene expression using RT-PCR on injured PDL cells. All materials' extracts induced $\mathrm{C} 5$ gene expression by injured PDL cells after 24 and $72 \mathrm{~h}$. b ELISA showed that both Gen-Os ${ }^{\circledR}$ materials significantly increased C5a secretion after 24 and $72 \mathrm{~h}$ while Bio-Oss ${ }^{\circledR}$ did not affect this secretion. Results are expressed in $\mathrm{pg} / \mathrm{mL}$. The asterisk indicates a statistical significant difference with the control

However, C5a quantification by ELISA showed that GenOs ${ }^{\circledR}$ materials significantly induced C5a secretion after 24 and $72 \mathrm{~h}$ as compared with the control (Fig. 2b). Bio-Oss ${ }^{\circledR}$ slightly increased C5a secretion but the difference was not statistically significant when compared with the control (Fig. 2b).

\section{Fixation of C5a on mesenchymal stem cells phosphorylates their C5aR}

PDL-secreted C5a was first tested for its binding to MSCs C5aR (Fig. 3a). C5a/C5aR binding significantly increased only with conditioned media from Gen-Os ${ }^{\circledR}$ (FE and FS) materials as compared with the control or Bio-Oss ${ }^{\circledR}$ (Fig. 3b). Furthermore, C5aR activation, investigated by its phosphorylation, was not affected by Bio-Oss ${ }^{\circledR}$ conditioned media while it significantly increased with both Gen-Os ${ }^{\circledR}$ (FE and FS) materials as compared with the control (Fig. 3c). Both fixation and phosphorylation were significantly decreased by incubation with the C5aR antagonist W54011 (Fig. 3b, c).

\section{Gen-Os $s^{\circledast}$ bone-filling materials induce mesenchymal stem cell proliferation}

A significant increase of MSCs proliferation was observed with Gen-Os ${ }^{\circledR}$ materials after 9 days. By contrast, this 


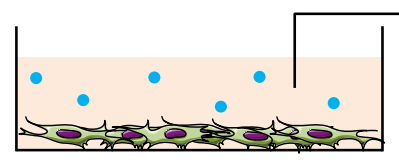

Injured PDL cells +/- material extracts

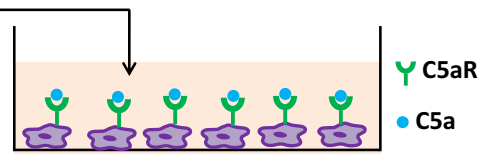

MSC
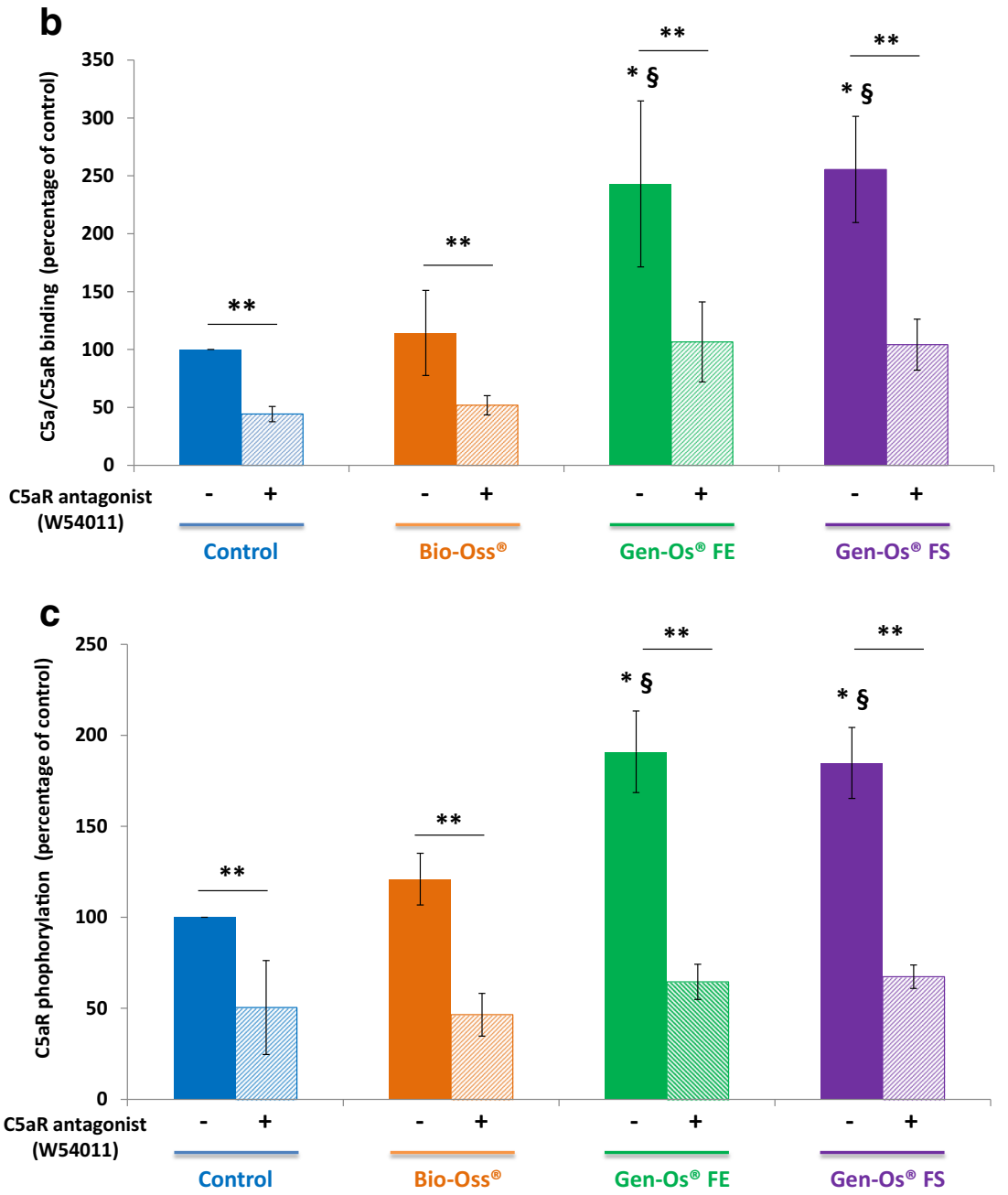

Fig. 3 Determination of C5a binding/phosphorylation of MSCs C5aR. a A schematic representation of the protocol used. Supernatants of injured PDL cells incubated with materials' extracts containing the secreted C5a (conditioned media) were applied onto MSCs which express C5a receptor (C5aR). b C5a/C5aR binding quantification: ELISA showed that a statistically significant increase of $\mathrm{C} 5 \mathrm{a} / \mathrm{C} 5 \mathrm{aR}$ binding with Gen-Os ${ }^{\circledR}$ (FE and FS) materials as compared with the control. Bio-Oss ${ }^{\circledR}$ did not increase this binding. c C5aR phosphorylation: a significant increase of $\mathrm{C} 5 \mathrm{aR}$ phosphorylation was observed with Gen-Os ${ }^{\circledR}$ (FE and FS) materials as

proliferation was decreased significantly after 6 and 9 days with Bio-Oss ${ }^{\circledR}$ as compared with the control (Fig. 4).

\section{Gen-0s ${ }^{\circledR}$-induced mesenchymal stem cell migration}

The migration assay in Boyden chambers is illustrated with a schematic view of the protocol used (Fig. 5a). The migration results are illustrated with representative pictures (Fig. 5b (a- compared with the control while no effect was observed with Bio-Oss ${ }^{\circledR}$. Results are expressed in percentage of control. Results are expressed as means \pm standard deviation. All results had statistically significant differences as compared with control condition $(p<0.05)$ The asterisk indicates a statistical significant difference with the control. Double asterisks indicate a statistical significant difference after adding C5aR antagonist. The section sign indicates a statistical significant difference between Gen$\mathrm{Os}^{\circledR}$ materials and Bio-Oss ${ }^{\circledR}$

d)). Quantitative analysis showed that MSCs migration significantly increased toward injured PDL cells incubated with all materials' extracts (Fig. 5c). However, incubation with Gen$\mathrm{Os}^{\circledR}$ induced a significantly higher migration than Bio$\mathrm{Oss}^{\circledR}$. Furthermore, adding the C5aR-specific antagonist significantly reduced MSCs migration, indicating that this migration occurs through specific $\mathrm{C} 5 \mathrm{a} / \mathrm{C} 5 \mathrm{aR}$ interactions (Fig. 5c). 


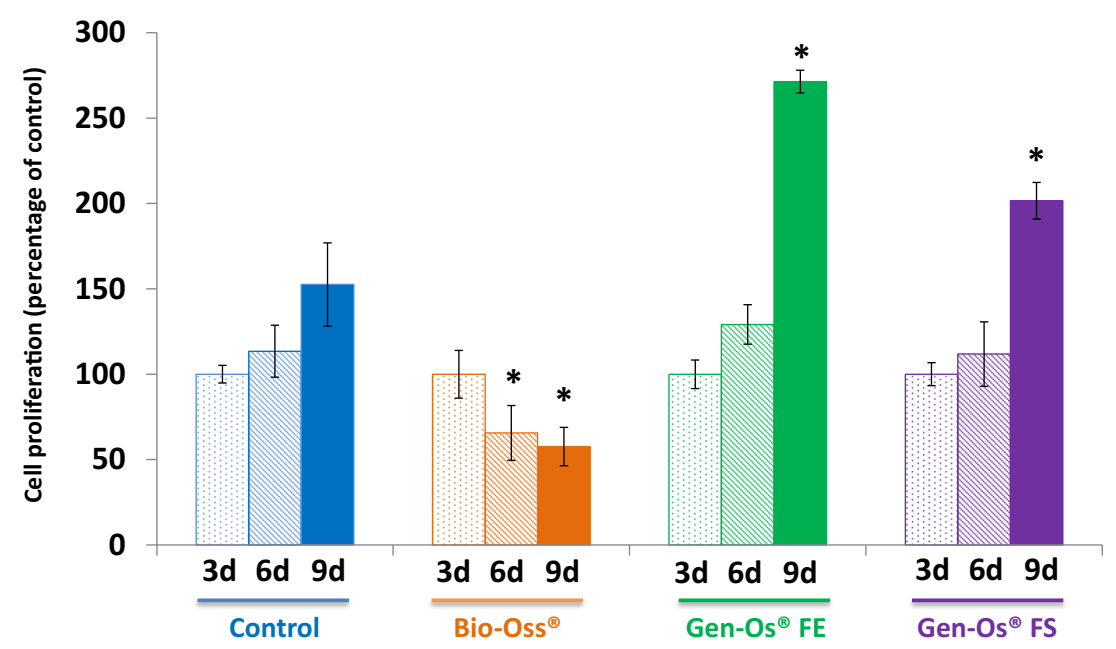

Fig. 4 Effects of materials on MSCs proliferation. Bio-Oss ${ }^{\circledR}$ significantly reduced cell proliferation after 6 and 9 days as compared with the control. By contrast, a significant increase of MSCs proliferation was observed with Gen-Os ${ }^{\circledR}$ (FE and FS) materials after 9 days. Results are expressed in percentage of control (3 days incubation as baseline). Results are

\section{Discussion}

This work demonstrates that injured PDL cells express complement $\mathrm{C} 5$ protein and secrete the bioactive $\mathrm{C} 5 \mathrm{a}$ fragment which binds to its receptor (C5aR) on mesenchymal stem cells. Moreover, bone-filling materials stimulate C5a production by injured PDL cells and this stimulation is higher with Gen-Os ${ }^{\circledR}$ bone-filling materials than with Bio-Oss ${ }^{\circledR}$. Binding of C5a to C5aR leads to its phosphorylation and the subsequent mesenchymal stem cell recruitment. This binding is specific and appears to be mediated by $\mathrm{C} 5 \mathrm{a}$ as inhibiting this fixation with the C5aR antagonist, W54011, significantly decreased C5a fixation on its receptor and the subsequent stem cell recruitment. Moreover, Gen-Os ${ }^{\circledR}$ bone-filling materials significantly induced MSCs proliferation while an inhibition was observed with Bio-Oss ${ }^{\circledR}$.

Bone-filling materials are applied directly onto the injured periodontal tissues in vivo. Although a direct contact is established between the material's surface and the underlying cells, small molecules leach out of the material and interact indirectly with PDL and MSCs. This situation is simulated in our investigation by studying the impact of three xenogeneic bone-filling material extracts on PDL cell secretion of C5a and the subsequent effects on MSCs proliferation and recruitment.

In this work, PDL cells expression of complement proteins is a new finding as this is the first report of $\mathrm{C} 5$ expression and bioactive C5a release by PDL cells. Complement proteins are known to be synthesized by the liver and some immune cells $[26,27]$. After activation, biologically active fragments such as C3a and C5a initiate the inflammatory reaction [28]. Recent data have demonstrated that the pulp fibroblasts synthesize complement proteins [20]. After incubation with lipoteichoic expressed as means \pm standard deviation. All results had statistically significant differences as compared with control condition $(p<0.05)$ The asterisk indicates a statistical difference with the control. The section sign indicates a statistical significant difference between GenOs ${ }^{\circledR}$ materials and Bio-Oss ${ }^{\circledR}$

acid simulating infection with Gram-positive bacteria, these cells release $\mathrm{C} 5 \mathrm{a}$ which binds to pulp stem cells and induce their recruitment at the LTA stimulation site. This suggests an implication of $\mathrm{C} 5 \mathrm{a}$ in the local regulation of the initial steps of pulp-dentin regeneration. Similarly, PDL cells express C5 mRNA and release the bioactive C5a fragment. The binding of this fragment on its receptor on MSCs lead to C5aR phosphorylation. This phosphorylation is followed by increased MSCs recruitment to C5a production site. This suggests that PDL cells are involved in the local regulation of the initial steps of bone regeneration via complement expression and synthesis.

Another potential effect of C5a protein secretion by PDL cells is the recruitment of macrophages. Indeed, C5a is known as an anaphylatoxin. It increases vessel permeability and allows macrophage cell recruitment from the bloodstream into injured or infected tissues. Macrophages express $\mathrm{C} 5 \mathrm{a}$ receptor and their recruitment has been investigated in response to $\mathrm{C} 5 \mathrm{a}$ production by pulp fibroblasts. This recruitment was even higher when pulp fibroblasts were injured or stimulated by lipoteichoic acid from Gram-positive bacteria [29]. The recruited macrophages may contribute to pathogens and cell debris elimination by phagocytosis which represents a prerequisite for tissue regeneration.

The differences in C5a secretion level between Gen-Os ${ }^{\circledR}$ and Bio-Oss ${ }^{\circledR}$ can be explained by (1) a possible toxic effect of Bio-Oss ${ }^{\circledR}$ as reported in Fig. 4 where Bio-Oss ${ }^{\circledR}$ inhibited cell proliferation. This result is in line with the study by Zimmerman and co-workers who reported a toxic effect of Bio-Oss ${ }^{\circledR}$ eluates on porcine mesenchymal stem cells likely due to toxic substances eluted from the Bio-Oss ${ }^{\circledR}$ material during extract preparation [30]. (2) Differences in the materials' structure and chemistry: our previous study showed that 
A

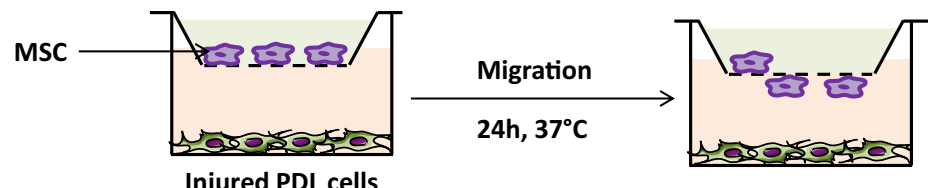

+/- material extracts

B
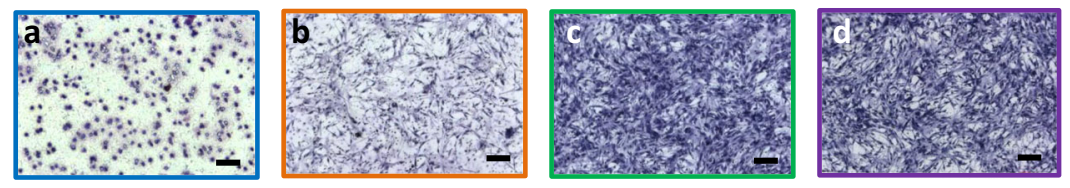

C

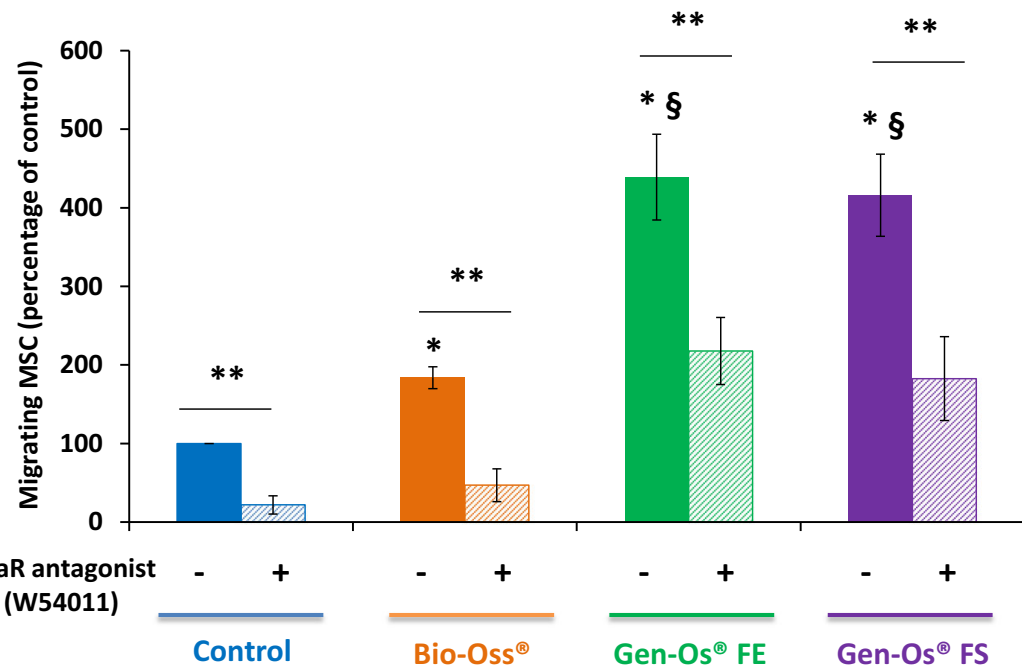

Fig. 5 Effects of materials on MSCs migration. a A schematic view of the migration assay using Boyden chambers. Injured PDL cells were cultured in the lower chambers (12-well plate) with the materials' extracts while MSCs were placed in the upper chambers $(8 \mu \mathrm{m}$ pore $)$ for $24 \mathrm{~h}( \pm$ W54011, C5a fixation inhibitor). After $24 \mathrm{~h}$, migrating cells were fixed, stained, and counted using optical microscopy. b Representatives pictures used for migrating cell count. (a) Control, (b) Bio-Oss ${ }^{\circledR}$, (c) Gen-Os ${ }^{\circledR} \mathrm{FE}$, and (d) Gen-Os ${ }^{\circledR}$ FS without C5a inhibitor (scales bars $=50 \mu \mathrm{m}$ ). Migration data analysis shows that Bio-Oss ${ }^{\circledR}$ and both Gen-Os ${ }^{\circledR}$ (FE

Bio-Oss ${ }^{\circledR}$ exhibits larger particle size than Gen-Os ${ }^{\circledR}$. Energy dispersive spectroscopy showed that Bio-Oss ${ }^{\circledR}$ had a lower calcium to phosphate ratio (1.63) when compared with both equine (2.07) and porcine (2.15) Gen-Os ${ }^{\circledR}$. Analysis by Fourier transform infrared spectroscopy showed a higher incorporation of carbonate in the apatite in Bio-Oss ${ }^{\circledR}$. The porcine and equine Gen-Os ${ }^{\circledR}$ displayed bands at 1650 and 1560 $\mathrm{cm}^{-1}$ characteristic of the amide $\mathrm{C}=\mathrm{O}$ stretching vibrations and $\mathrm{N}-\mathrm{H}$ bending vibrations indicating the presence of collagen in both Gen-Os ${ }^{\circledR}$ samples in bands at 3450 and $1450 \mathrm{~cm}^{-1}$ $[23,31]$. The manufacturing procedure of Gen-Os ${ }^{\circledR}$ materials at low temperatures allows the preservation of the natural collagen matrix [32]. Bio-Oss ${ }^{\circledR}$ used in this experience had no collagen incorporated. It has been suggested that the presence of collagen creates a favorable environment for bone regeneration [33]. Thus, a difference in C5a secretion levels and FS) significantly increased MSCs migration as compared with the control. Use of C5a fixation inhibitor significantly decreased the migration levels for all conditions. Results are expressed as means \pm standard deviation. All results had statistically significant differences as compared with control condition $(p<0.05)$ The asterisk indicates a statistical significant difference with the control. Double asterisks indicate a statistical significant difference after adding $\mathrm{C} 5 \mathrm{aR}$ antagonist. The section sign indicates a statistical significant difference between Gen-Os ${ }^{\circledR}$ materials and Bio-Oss ${ }^{\circledR}$

between the materials can be due to the chemical components leaching out of the materials. Indeed, complement can be activated by its interaction with biomaterials containing free $\mathrm{OH}$, $\mathrm{NH}_{3}$, or $\mathrm{COOH}$ groups, which are known to activate the complement classical pathway [34, 35].

MSCs expression of C5aR reported here is in line with previous investigations showing C5aR expression by osteoblasts and osteoclasts, as well as human MSCs, undergoing osteogenic differentiation, and that their activation by $\mathrm{C} 5 \mathrm{a}$ induces a strong chemotactic activity that might play a regulatory role in fracture healing in intramembranous and in endochondral ossification [36]. By contrast, Gen-Os ${ }^{\circledR} \mathrm{FE}$ and FS induced a significant increase in C5a secretion, its binding to $\mathrm{C} 5 \mathrm{aR}$ on MSCs and the induction of their recruitment. These effects of C5a correspond to the initial steps of bone regeneration which requires the presence and proliferation of stem 
cells and their recruitment and differentiation for osteogenesis at the injury site [37].

Thus, while bone-filling materials act as a bio-resorbable scaffold providing a 3-dimensional environment for MSCs attachment and proliferation [38], the production and release of C5a at the bone-filling material application site is of prime importance as it acts as a chemotactic signal for MSCs recruitment. An increased C5a production would guide MSCs recruitment to the injury and bone-filling material application site thus initiating the bone regeneration process. A migration assay was also performed to study the effects bone substitute extracts alone on MSCs recruitment. Under these conditions, no migration was observed indicating that MSCs migration is only due to PDL cell secretion (data not shown). While this type of work can be extended to several bone-filling materials and dentin chips, we used Bio-Oss ${ }^{\circledR}$ and Gen-Os ${ }^{\circledR}$ materials based on our previous experimental knowledge of these materials which showed an angiogenic and an osteogenic potential [23].

Overall, this work allows understanding the molecular and cellular mechanisms underlying this regeneration process. Interaction of bone-filling materials with the injured PDL cells modulates the local environment by inducing C5a secretion. Bone-filling materials are not physiologically inert. After fixation on MSCs receptor, C5a recruits stem cells to the C5a production site and allows stem cells to regenerate bone in the filling material site. Within the limits of this study in vitro, Gen-Os ${ }^{\circledR}$-filling materials of equine and porcine origins have a higher potential than bovine Bio-Oss ${ }^{\circledR}$ on MSCs proliferation and C5a-dependent recruitment to the PDL injury site and the subsequent bone regeneration.

Acknowledgments The authors thank Dr. Jean-Charles GARDON for providing the teeth.

Funding information The work was supported by Aix-Marseille University and CNRS.

\section{Compliance with ethical standards}

Conflict of interest The authors declare that they have no conflict of interest.

Ethical approval This article does not contain any studies with human participants or animals performed by any of the authors.

Informed consent For this type of study, formal consent is not required.

\section{References}

1. Tan WL, Wong TLT, Wong MCM, Lang NP (2012) A systematic review of post-extractional alveolar hard and soft tissue dimensional changes in humans. Clin Oral Implants Res 23:1-21. https://doi. $\operatorname{org} / 10.1111 / \mathrm{j} .1600-0501.2011 .02375 . x$
2. Jamjoom A, Cohen RE (2015) Grafts for ridge preservation. J Funct Biomater 6:833-848. https://doi.org/10.3390/jfb6030833

3. Bassir S, Alhareky M, Wangsrimongkol B, Jia Y, Karimbux N (2018) Systematic review and meta-analysis of hard tissue outcomes of alveolar ridge preservation. Int $J$ Oral Maxillofac Implants 33:979-994. https://doi.org/10.11607/jomi.6399

4. Barone A, Aldini NN, Fini M, Giardino R, Calvo Guirado JL, Covani U (2008) Xenograft versus extraction alone for ridge preservation after tooth removal: a clinical and histomorphometric study. J Periodontol 79:1370-1377. https://doi.org/10.1902/jop. 2008.070628

5. Cortellini P (2000) Tonetti MS (2015) Clinical concepts for regenerative therapy in intrabony defects. Periodontol 68:282-307. https://doi.org/10.1111/prd.12048

6. Giuliani A, Iezzi G, Mazzoni S, Piattelli A, Perrotti V, Barone A (2018) Regenerative properties of collagenated porcine bone grafts in human maxilla: demonstrative study of the kinetics by synchrotron radiation microtomography and light microscopy. Clin Oral Investig 22:505-513. https://doi.org/10.1007/s00784-017-2139-6

7. Alfonsi F, Borgia V, Iezzi G et al (2017) Molecular, cellular and pharmaceutical aspects of filling biomaterials during the management of extraction sockets. Curr Pharm Biotechnol 18:64-75. https://doi.org/10.2174/1389201018666161223152607

8. Lin W, Xu L, Zwingenberger S, Gibon E, Goodman SB, Li G (2017) Mesenchymal stem cells homing to improve bone healing. J Orthop Transl 9:19-27. https://doi.org/10.1016/j.jot.2017.03.002

9. Wang L, Li Y, Chen J et al (2002) Ischemic cerebral tissue and MCP-1 enhance rat bone marrow stromal cell migration in interface culture. Exp Hematol 30:831-836. https://doi.org/10.1016/S0301472X(02)00829-9

10. Puré E, Cuff CA (2001) A crucial role for CD44 in inflammation. Trends Mol Med 7:213-221. https://doi.org/10.22203/eCM. v026a09

11. Hemeda H, Jakob M, Ludwig A-K et al (2010) Interferon-gamma and tumor necrosis factor-alpha differentially affect cytokine expression and migration properties of mesenchymal stem cells. Stem Cells Dev 19:693-706. https://doi.org/10.1089/scd.2009. 0365

12. Liu J, Kerns DG (2014) Mechanisms of guided bone regeneration: a review. Open Dent J 8:56-65. https://doi.org/10.2174/ 1874210601408010056

13. Mijiritsky E, Ferroni L, Gardin C et al (2017) Porcine bone scaffolds adsorb growth factors secreted by MSCs and improve bone tissue repair. Materials 10:1054. https://doi.org/10.3390/ ma10091054

14. Murphy CM, O’Brien FJ, Little DG, Schindeler A (2013) Cellscaffold interactions in the bone tissue engineering triad. Eur Cell Mater 26:120-132. https://doi.org/10.22203/eCM.v026a09

15. Ignatius A, Ehrnthaller C, Brenner RE et al (2011) The anaphylatoxin receptor $\mathrm{C} 5 \mathrm{aR}$ is present during fracture healing in rats and mediates osteoblast migration in vitro: The Journal of Trauma: Injury. Infect Crit Care 71:952-960. https://doi.org/10. 1097/TA.0b013e3181f8aa2d

16. Ricklin D, Hajishengallis G, Yang K, Lambris JD (2010) Complement: a key system for immune surveillance and homeostasis. Nat Immunol 11:785-797. https://doi.org/10.1038/ni.1923

17. Giannini E, Boulay F (1995) Phosphorylation, dephosphorylation, and recycling of the C5a receptor in differentiated HL60 cells. J Immunol 154:4055-4064

18. Schraufstatter IU, Discipio RG, Zhao M, Khaldoyanidi SK (2009) $\mathrm{C} 3 \mathrm{a}$ and $\mathrm{C} 5 \mathrm{a}$ are chemotactic factors for human mesenchymal stem cells, which cause prolonged ERK1/2 phosphorylation. J Immunol 182:3827-3836. https://doi.org/10.4049/jimmunol.0803055

19. Chmilewsky F, Jeanneau C, Laurent P, Kirschfink M, About I (2013) Pulp progenitor cell recruitment is selectively guided by a 
C5a gradient. J Dent Res 92:532-539. https://doi.org/10.1177/ 0022034513487377

20. Chmilewsky F, Jeanneau C, Laurent P, About I (2014) Pulp fibroblasts synthesize functional complement proteins involved in initiating dentin-pulp regeneration. Am J Pathol 184:1991-2000. https://doi.org/10.1016/j.ajpath.2014.04.003

21. Li K, Sacks SH, Zhou W (2007) The relative importance of local and systemic complement production in ischaemia, transplantation and other pathologies. Mol Immunol 44:3866-3874. https://doi. org/10.1016/j.molimm.2007.06.006

22. Jeanneau C, Rufas P, Rombouts C et al (2015) Can pulp fibroblasts kill cariogenic bacteria? Role of complement activation. J Dent Res 94:1765-1772. https://doi.org/10.1177/0022034515611074

23. Rombouts C, Jeanneau C, Camilleri J, Laurent P, About I (2016) Characterization and angiogenic potential of xenogeneic bone grafting materials: role of periodontal ligament cells. Dent Mater J 35:900-907. https://doi.org/10.4012/dmj.2016-005

24. Mathieu S, Jeanneau C, Sheibat-Othman N et al (2013) Usefulness of controlled release of growth factors in investigating the early events of dentin-pulp regeneration. J Endod 39:228-235. https:// doi.org/10.1016/j.joen.2012.11.007

25. Jia M, Shi Z, Yan X et al (2018) Insulin and heparin-binding epidermal growth factor-like growth factor synergistically promote astrocyte survival and proliferation in serum-free medium. $\mathrm{J}$ Neurosci Methods. https://doi.org/10.1016/j.jneumeth.2018.06.002

26. Morris KM, Aden DP, Knowles BB, Colten HR (1982) Complement biosynthesis by the human hepatoma-derived cell line HepG2. J Clin Invest 70:906-913. https://doi.org/10.1172/ JCI110687

27. Lubbers R, van Essen MF, van Kooten C, Trouw LA (2017) Production of complement components by cells of the immune system: production of complement components. Clin Exp Immunol 188:183-194. https://doi.org/10.1111/cei.12952

28. Peng Q, Li K, Sacks SH, Zhou W (2009) The role of anaphylatoxins $\mathrm{C} 3 \mathrm{a}$ and $\mathrm{C} 5 \mathrm{a}$ in regulating innate and adaptive immune responses. Inflamm Allergy Drug Targets 8:236-246. https://doi.org/10.2174/187152809788681038

29. Giraud T, Rufas P, Chmilewsky F et al (2017) Complement activation by pulp capping materials plays a significant role in both inflammatory and pulp stem cells' recruitment. J Endod 43:11041110. https://doi.org/10.1016/j.joen.2017.02.016
30. Zimmermann CE, Gierloff M, Hedderich J, Açil Y, Wiltfang J, Terheyden H (2011) Biocompatibility of bone graft substitutes: effects on survival and proliferation of porcine multilineage stem cells in vitro. Folia Morphol (Warsz) 70:154-160

31. Adams BR, Mostafa A, Schwartz Z, Boyan BD (2014) Osteoblast response to nanocrystalline calcium hydroxyapatite depends on carbonate content: osteoblasts and Carbonated Hydroxyapatite. J Biomed Mater Res 102:3237-3242. https://doi.org/10.1002/jbm.a. 34994

32. Figueiredo M, Henriques J, Martins G et al (2010) Physicochemical characterization of biomaterials commonly used in dentistry as bone substitutes-comparison with human bone: biomaterials in dentistry as bone substitutes. J Biomed Mater Res 92B:409-419. https://doi.org/10.1002/jbm.b.31529

33. Barone A, Nannmark U (2014) Bone, biomaterials \& beyond. Edra Masson. p 200

34. Andersson J, Ekdahl KN, Larsson R et al (2002) C3 Adsorbed to a polymer surface can form an initiating alternative pathway convertase. J Immunol 168:5786-5791. https://doi.org/10.4049/ jimmunol.168.11.5786

35. Nilsson B, Korsgren O, Lambris JD, Ekdahl KN (2010) Can cells and biomaterials in therapeutic medicine be shielded from innate immune recognition? Trends Immunol 31:32-38. https://doi.org/ 10.1016/j.it.2009.09.005

36. Ignatius A, Schoengraf $P$, Kreja L, Liedert A, Recknagel S, Kandert S, Brenner RE, Schneider M, Lambris JD, Huber-Lang M (2011) Complement $\mathrm{C} 3 \mathrm{a}$ and $\mathrm{C} 5 \mathrm{a}$ modulate osteoclast formation and inflammatory response of osteoblasts in synergism with IL-1 $\beta$. J Cell Biochem 112:2594-2605. https://doi.org/10.1002/jcb.23186

37. Schraufstatter IU (2015) Complement activation in the context of stem cells and tissue repair. World J Stem Cells 7:1090. https://doi. org/10.4252/wjsc.v7.i8.1090

38. Hutmacher DW (2000) Scaffolds in tissue engineering bone and cartilage. Biomaterials 21:2529-2543. https://doi.org/10.1016/ S0142-9612(00)00121-6 